University of Michigan Law School

University of Michigan Law School Scholarship Repository

1976

\title{
Citizen Access to Judicial Review of Administrative Action in a Transnational and Federal Context
}

\author{
Eric Stein \\ University of Michigan Law School \\ Joseph Vining \\ University of Michigan Law School, jvining@umich.edu
}

Available at: https://repository.law.umich.edu/articles/1632

Follow this and additional works at: https://repository.law.umich.edu/articles

Part of the Courts Commons, European Law Commons, Jurisdiction Commons, Organizations Law Commons, and the Transnational Law Commons

\section{Recommended Citation}

Vining, Joseph. "Citizen Access to Judicial Review of Administrative Action in a Transnational and Federal Context." E. Stein, co-author. Am. J. Int'I L. 70 (1976): 219-41.

This Article is brought to you for free and open access by the Faculty Scholarship at University of Michigan Law School Scholarship Repository. It has been accepted for inclusion in Articles by an authorized administrator of University of Michigan Law School Scholarship Repository. For more information, please contact mlaw.repository@umich.edu. 


\title{
CITIZEN ACCESS TO JUDICIAL REVIEW OF ADMINISTRATIVE ACTION IN A TRANSNATIONAL AND FEDERAL CONTEXT
}

\author{
By Eric Stein and G. Joseph Vining * \\ The Indivmoal Crtizen in International Law
}

In an international legal order dominated by states, the individual citizen is generally viewed as lacking international legal personality. It is true with little exception that an individual cannot appear in an international forum, political or judicial, to press his rights. Despite the dramatically increased emphasis upon international protection of basic human rights, individuals have been given access to international dispute-settlement machinery in only a few isolated instances within the United Nations system, and on a regional level pursuant to the European Convention on Human Rights. ${ }^{1}$

The Paris Treaty establishing the European Coal and Steel Community (ECSC) and the Rome Treaties establishing the European Atomic Energy Community (EURATOM) and the European Economic Community (EEC, the Common Market) are the only international agreements providing for a judicial tribunal of general compulsory jurisdiction open not only to member states and Community institutions but individual citizens as well. The purpose of this essay is to explore the case law of the Court of Justice of the Communities and the considerations that may have motivated that Court in its effort to define limits on access by individuals seeking judicial review of acts of Community institutions and to inquire whether

* Of the Board of Editors.

- Professor of Law, University of Michigan Law School.

The substance of this article was presented at the workshop organized by the Institute of Advanced Legal Studies in London, July 1-4, 1975.

1 International civil servants may press their service-connected grievances before administrative tribunals established by the United Nations and the specialized agencies. M. B. Akehurst, The Law Governing Exrployment in International Organizations (1967); Byong Chut Koh, The United Natrons admintstrattve Trubunal (1966). If the state concerned consents, an individual may complain against it to a committee of experts under the UN sponsored Convention on the Elimination of All Forms of Racial Discrimination. Schwelb, The International Convention on the Elimination of All Forms of Racial Discrimination, I5 INT'L * CoMp. L.Q. 996 (1966). Pursuant to procedures evolved in UN General Assembly Committees and in certain other UN bodies, individuals may file petitions and even may be heard in person. Individuals may complain directly to the European Commission of Human Rights if the state against which the complaint was lodged recognizes such jurisdiction, but only the states contracting parties and the Commission have access to the European Court of Human Rights. European Convention for the Protection of Human Rights and Fundamental Freedoms, Arts. 25 and 48, 213 UNTS 221 (1955). 
experience with judicial review of administrative action in a federation may be relevant to the evolution of transnational European administrative law.

\section{THReE CASES}

A convenient way of introducing the subject is to present three little dramas in contemporary costume, drawn from three different milieux:

(1) The Federal Comptroller of Currency, an agency supervising federal banks in the United States, issued a regulation allowing federal banks to expand their activities into the business of selling data processing services. A trade association of companies also engaged in selling data processing services and claiming loss of profit and customers sued the Comptroller to obtain review and annulment of the regulation. The data processing companies relied on a federal statute which prohibited banks from engaging in any activity other than the performance of bank services. In 1970 the Supreme Court of the United States upheld their standing to sue. ${ }^{2}$

(2) In the nineteen sixties, the Parliament of the German Federal Republic appropriated funds to the individual German States (Länder) for the purpose of subsidizing construction of wine vaults by German wine producers and thus increasing their competitive position in the Common Market by improving the quality of their wine. The Land in question allocated the subsidies to wine producers but refused the application of a company engaged in wine marketing. The company sued for review and annulment of the Land decisions granting the subsidies to producers, alleging illegal denial of an equal opportunity to compete. Its business consisted of entering into long-term contracts with wine producers for the annual purchase of quantities of wine at a minimum price, storing the wine, and ultimately marketing it. As a result of the subsidies, the producers were now able to market wine directly to consumers at a cheaper price than competing retailers who like the plaintiff company did not have access to the subsidy. The Federal Administrative Court upheld the plaintiff company's standing to institute judicial review. ${ }^{3}$

(3) In 1968, the Commission of the European Communities decided to grant substantial subsidies from Community funds to three Italian sugar refineries to enlarge their production. The award was conditioned upon enlargement by the Italian Government of the production quotas allotted to the three refineries within the Italian quota fixed by the Community. The plaintiffs, competing sugar refinery enterprises who did not get any subsidies, sued in the Court of Justice of the Communities for review and annulment of the Commission's decisions, alleging unlawful distortion of competition in violation of the articles of the Treaty on subsidies, because their own production quotas were to be reduced to make possible the required enlargement of the quotas of the three subsidized competitors. The

2 Association of Data Processing Service Organizations, Inc. v. Camp, 397 U.S. 150 (1970).

3 Judgment of Aug. 30, 1968, 30 BVerwGE 191. 
Court denied standing to sue on the ground that the plaintiffs failed to demonstrate a direct and individual concern. ${ }^{4}$

Thus in the United States private plaintiffs claiming consequential harm have been given standing to contest a general regulation. In Germany they have been permitted to contest decisions addressed to third parties. But in analogous situations in the European Economic Community (EEC) they have been denied standing to sue. Two of the three milieux are more or less mature federations in which citizens are directly subject to federal and state laws. The third is different-a hybrid, "a new legal order in international law." : It is a treaty-based international organization, but is distinctive among such organizations in its broad impact upon the rights and obligations of individual citizens.

To what extent does or should this distinction make a difference? Should or will the experience of the Community follow that of mature political federations? Or should we approach each sui generis and see nothing remarkable in current differences in treatment of apparently similar problems?

\section{The Federation and the Comanuntry:} Some Disstmenarties

The comparative method, in law or in any other discipline, has its problems. Above all there is a danger of losing sight of controlling dissimilarities behind the smokescreen of superficial likeness. It may help to avoid pitfalls if we review some of the relevant similarities and differences between the European Economic Community and a federal system as exemplified by the United States.

At the core of our inquiry is the position of the individual before governmental authority in an increasingly complex and technology-based society, which now exists on both sides of the Atlantic. On one hand government regulation steadily widens, and on the other individuals and groups demand ever greater recognition and participation in governmental processes. In the United States as in the Community, governmental authority is divided among separate hierarchies of institutions exercising normative powers. The United States has states with different constitutions, a federal government, fifty state judiciaries, and a federal judiciary. But in the United States, the power of the federation dwarfs the states' power. In the Community the balance goes the other way. In the United States there is little question about the basic legitimacy of the governmental institutions, even though today the Watergate cloud is still hovering over them, while in the Communities the institutions are brittle and as yet have little grass roots participation. Moreover, Community lawmaking is in

\footnotetext{
: Cases 10 and 18/68, Società "Eridania" Zuccherifici Nazionali et al. v. Commission of the European Communities, I5 Recuent dE LA JuRrsprudence DE LA COUR DE Justice des Conarunautís Européennes (Rec.) 459 (1969).

3 The Court of Justice of the Communities in Case 26/62, N.V. Algemene Transporten Expeditie Andernemung van Gend en Loos v. Nederlandse Tariefcommissie, 9 REc. 1 (1963); [1963] European Court Reports (ECR) 1 at 12; [1963] Conmon Market Law Reports (C.M.L.R.) 105; Commerce Clearing House, Chicago, Common Market Reporter (CCH CoMm. MKt. Rep.) $\{8008$.
} 
the hands of an executive. There is no popularly based legislature. In the American federation, federal agencies and federal courts execute federal legislation (with some important exceptions such as federal grant programs where implementation is left in considerable part to the states). But in the Community, member states carry the bulk of the responsibility for implementing Community law: state officials issue import licenses and collect customs duties; state parliaments transform major directives into national law; and state courts decide controversies involving Community law, albeit after preliminary ruling on Community law questions by the Court of Justice. ${ }^{6}$ This broad decentralization and delicate symbiotic relationship between national and Community institutions at the political as well as the judicial levels, to which there is no real analogy in the United States, is a feature of crucial importance in evaluating the case law on standing before the Court of Justice. The Community is a body at the borderline between the federal and the international and in international law the very notion of an individual having independent standing to sue before an international tribunal is little short of revolutionary.

\section{The Standing Question: What the Court OF JUSTICE SATD}

With these differences in mind, let us turn to the similarities between the American federation and the Community bearing directly upon the standing question. In each the formal source of law determining the requirements of standing can be found in principle in a single normative provision: in Article 173 of the EEC Treaty ${ }^{7}$ and in section 10 of the federal Administrative Procedure Act. ${ }^{8}$ In addition, however, federal statutes often provide specifically for judicial review of specified types of administrative action. Similarly, in the Community certain regulations, such as Regulation 17 implementing the Treaty rules of competition, might have the effect of broadening individual access to judicial review. ${ }^{\circ}$

Article 173 sets no limitations whatsoever upon the standing of member states to contest any normative act of the Commission or the Council, nor for that matter upon the standing of the Commission to contest acts of the Council and vice versa. The much discussed second paragraph of that Article provides that

[a]ny natural or legal person may ... institute proceedings against a decision addressed to that person or against a decision which, although in the form of a regulation or a decision addressed to another person, is of direct and individual concern to the former.

${ }^{6}$ Art. 177 of the EEC Treaty.

7 'The corresponding articles in the other Community treaties are Article 33 of the ECSC Treaty and Article 146 of the Euratom Treaty.

85 U.S.C. $\$ 702$ (Supp. V, 1965-1969). This discussion is limited to judicial review of acts of federal administrative agencies which have both rulemaking and decisionmaking authority. We do not address the special problem of judicial review of congressional acts for constitutionality.

- Daig in $\mathrm{H}$. von der Groeben, H. von Boeckh, J. Thiesinc, 2 Kommentan zum EWG-Vertrag 209 at 234 (2nd ed. 1974); Peters in 3 C.M.L. Rev. 233 at 241 (1965). 
The posture of the Court of Justice with regard to this provision was set in two groups of early cases in which the question of individual standing was raised for the first time: Cases 16-17/62 and 19-22/62 in which associations of producers and associations of traders respectively sued for annulment of Council regulations, ${ }^{10}$ and the Plaumann Case 25/62, ${ }^{11}$ in which a German importer of citrus fruit sought to contest a Commission decision addressed to the German Government refusing to authorize a reduction of the common external tariff on certain fruit imports from third states. The Court denied standing in both instances and adopted a strict reading of the requirement of "direct and individual concern." It did so despite an express recognition of the principle in the Plaumann case that provisions for access to legal remedy should never be narrowly construed.12

Judging by what the Court said, the factor that influenced it most was the difference between the language in the second paragraph of Article 173 and the corresponding provision in the earlier Treaty Establishing the Coal and Steel Community. ${ }^{13}$ That latter provision, which expressly grants standing to contest acts of general application on the ground of détournement de pouvoir (misuse of powers, abuse of discretion) affecting a

${ }^{10}$ Cases 16/62 and 17/62, Confédération Nationale des Producteurs de Fruits et Légumes et al. v. Council, 8 Rec. 901 (1962); [1962] ECR 471; [1963] C.M.L.R. 160; CCH Conar. Mrt. Rep. $\$ 8005$ at 7186. Cases 19/62-22/62, Fédération Nationale de la Boucherie en Gros, etc. v. Council, 8 Rec. 943 (1962); [1962] ECR 491; [1963] C.M.L.R. 160; CCH Coxar. MKr. REP. 『8006.

${ }^{21}$ Case 25/62, Plaumann \& Co. v. Commission, 9 REc. 197 (1963); [1963] ECR 95; [1964] C.M.L.R. 29; CCH CoMm. MKr. Rep. \8013 at 7274.

12 In the above cases the attorneys for the defendant Council and Commission urged an even more restrictive interpretation that would have denied any association capacity to sue as such under any circumstances despite the specific Treaty language to the contrary ("any ... legal person") and that would not recognize a government as a "person" within the meaning of the second paragraph of Article 173. The Court rejected these assertions and on this issue followed the conclusions of its Advocates General.

${ }^{15}$ Article 33 of the ECSC Treaty reads: “. . . Undertakings or the associations referred to in Article 48 may, under the same conditions, institute proceedings against decisions or recommendations concerning them which are individual in character or against general decisions or recommendations which they consider to involve a misuse of powers (détournement de pouvoir) affecting them (à leur égard-ihnen gegeniiber)." Compare the above language "decisions . . . concerning them" with the requirement of "direct and individual concern" in the corresponding EEC Art. 173(2) supra. There is considerable literature comparing the ECSC and the EEC Treaties on this issue and commenting on the case law. See e.g. G. Bebr, Judictal Control of the Eunopean Comarunttes 68-77 (1962); A. Tizzano, La Corte di Gustrzia delle Comiaruntrì Europee 396-415 (1967) and also in R. Quadri, R. Monaco, A. Trabucch, 3 Trattato Istituttvo della Cosntuntà Economita Europea, Conamentanio 1277-85 (1965); Daig in Konmentar supra note 9, at 222-36; C. H. ULE, EATPFIEHLT ES SICH, DIE BESTLALMUNGEN DES EUROPÄISCHEN GEMEINSCHAFTSRECHTS ÜBER

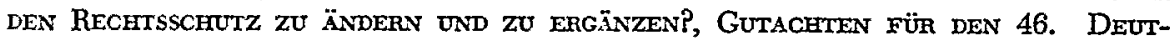
SCHEN JuRISTENTAG 13-32 (1966); Bebr, Recours en annulation et en carrence in W. J. Ganshof van der Meersch (ed.), Les Novelles, Drot des Comprunautés EunopéENnes 309-19 (1969) with bibliography at 309; Rasquin et Chevallier, L'article 173, alinéa 2 du Traité C.E.E., 2 Rev. TRMr. DR. EUR. 31 (1966); Barav, Direct and Individual Concern: An Almost Insurmountable Barrier to the Admissibility of Individual Appeal to the EEC Court, 11 C.M.L. REv. 191 (1974). 
plaintiff, had been given a rather liberal interpretation by the Court. The Court concluded from the differences between the two treaties that the authors of the EEC Treaty deliberately intended to restrict access of individuals to the Court, presumably because of the much broader power to issue general regulations granted to the EEC institutions and the much wider range of persons affected by the EEC Treaty. "It is not for the Court to pass upon the merits of such system," the Court stated, "since the latter clearly stems from the text under scrutiny."

The formula that the Court evolved in the early cases for the application of the second paragraph of Article 173 may be summarized as follows:

(1) An act is a "regulation"-as opposed to a "decision in the form of a regulation" 14-if, by its "legal nature," it applies to categories of persons treated theoretically. Private persons may not contest such a general regulation under any circumstances. ${ }^{15}$

(2) "Decisions" may be contested, but persons other than those to whom a decision was addressed must show not only a direct concern but also an individual concern. They can claim an individual concern only if the decision affects them because of factors peculiar to them or by reason of circumstances "in which they are differentiated from all other persons and by virtue of these factors distinguishes them individually just as in the case of the persons addressed." 18

Professor Waelbroeck has called the second part of this formula "not enlightening," which is a resounding understatement. The real question, he wrote, is to know just what the characteristics or fact situations are that "individualize" a person. ${ }^{17}$ It is nevertheless this formula or its variant that the Court has repeated in every case and applied to deny standing to all the "natural or legal persons" who thus far have come before it as

14 According to Article 189, a "regulation" is "directly applicable" by national courts and other authorities throughout the Community territory.

15 Cases 16/62 and 17/62, Confédération Nationale, supra note 10 . The Court added in Confédération Nationale that it would look beyond the official designation of the act as a "regulation":

Consequently, in order to determine in doubtful cases whether one is concerned with a decision or a regulation, it is necessary to ascertain whether the measure in question is of individual concern to specific individuals. In these circumstances, if a measure entitled by its author a regulation contains provisions which are capable of being not only of direct but also of individual concern to certain natural or legal persons, it must be admitted, without prejudice to the question whether that measure considered in its entirety can be correctly called a regulation, that in any case those provisions do not have the character of a regulation and may therefore be impugned by those persons under the terms of the second paragraph of Article 173.

[1962] ECR at 478-79. In support of a more liberal interpretation, see A. TrzzANo, supra note 13, at 404-11. But see Bebr, Recours en annulation et en carrence, supra note 13, at 318. On the above cases, see note by Cartou in [1962] Siney JunuspruDENCE 126.

16 Case 25/62, Plaumann, supra note 11, [1963] ECR at 107. Since the plaintiff in this case was not concerned "individually," the Court found it unnecessary to deal with the question of "direct" concern.

${ }_{17}$ Waelbroeck, Les compétences de la Cour de Justice (II), [1971] REv. Cnrrique DE JURUSRRUDENCE BELGE 513 at 530. 
plaintiffs, ${ }^{18}$ with the exception of three cases. Let us consider this triad in some detail since it may be easier to divine the Court's criteria from cases where standing was granted than from the much more numerous cases where it was denied.

\section{The Trlad Where Standing Was Allowed}

In the Toepfer case, ${ }^{19}$ the German Government import agency posted a zero levy on the import of corn for a specific date as a result of a Com-

${ }^{18}$ The cases in which this paragraph was applied or discussed are: Cases 16 \& 17/62, Confédération Nationale des Producteurs de Fruits et Légumes et al. v. Council, 8 Rec. 901 (1962); [1962] ECR 471; [1963] C.M.L.R. 160; CCH Conrm. MET. REP. $\{8005$. Cases 19-22/62, Fédération Nationale de la Boucherie en Gros et du Commerce en Gros des Viandes et al. v. Council, 8 Rec. 943 (1962); [1962] ECR 491; [1963] C.M.L.R. 160; CCH Comar. MKT. ReP. \8006. Cases 31 \& 33/62, Milchwerke Heinz Wöhrmann \& Sohn KG et Alfons Lütticke GmbH v. Commission, 8 REc. 965 (1962); [1962] ECR 501; [1963] C.M.L.R. 152; CCH CoMr. MkT. ReP. \$8007. Case 25/62, Plaumann \& Co. v. Commission, 9 Rec. 197 (1963); [1963] ECR 95; [1964] C.M.L.R. 29; CCH CoMnr. MKT. ReP. $\$ 8013$. Case 1/64, Glucoseries Réunies v. Commission, 10 Rec. 811 (1964); [1964] ECR 413; [1964] C.M.L.R. 596; CCH Conar. Mkt. Rep. \$8024. Case 38/64, Getreide-Import Gesellschaft v. Commission, 11 Rec. 263 (1965); [1965] ECR 204; [1965] C.M.L.R. 276; CCH CoMrM. Mkr. Rep. \8033. Case 40/64, Marcello Sgarlata et al. v. Commission, 11 Rec. 279; (1965); [1965] ECR 215; [1966] C.M.L.R. 314; CCH CoMm. MxT. Rep. \8034. Cases 106 \& 107/63, Alfred Toepfer et Getreide-Import Gesellschaft v. Commission, II Rec. 525 (1965); [1965] ECR 405; [1966] C.M.L.R. 111; CCH Comm. Mkr. ReP. [8031. Case 30/67, Industria Molitoria Imolese et al. v. Council, 14 Rec. 171 (1968); [1968] ECR 115; CCH Coגar. MKr. Rep. [8060. Case 6/68, Zuckerfabrik Watenstedt GmbH v. Council, 14 Rec. 595 (1968); [1968] ECR 409; [1969] C.M.L.R. 26; CCH Conar. Mkt. REP. $₫ 8063$. Cases 10 \& 18/68, Società "Eridania" Zuccherifici Nazionali et al. v. Commission, 15 Rec. 459 (1969); CCH Conm. Mkt. Rep. $\llbracket 8099$. Cases 63 \& 64/69, La Compagnie française commerciale et financière, SA v. Commission, 16 Rec. 205 (1970); [1970] C.M.L.R. 369; CCH Cosnr. Mkт. Rep. 『8090, 18091. Case 65/69, La Compagnie d'approvisionnement, de transport et de credit, SA v. Commission, 16 Rec. 229 (1970); [1970] C.M.L.R. 369; CCH CoMrM. MKT. Rep. โ8092. Case 69/69, SA Alcan Aluminium Raeren et al. v. Commission, 16 Rec. 385 (1970); [1970] C.M.L.R. 337; CCH Congr. MkT. Rep. $\llbracket 8110$. Case 15/70, Amedeo Chevalley v. Commission, 16 Rec. 975 (1970); CCH CoMar. Mkr. ReP. โ8115. Cases 41-44/70, NV International Fruit Co. et al. v. Commission, 17 REC. 411 (1971); CCH Coxrm. Mkt. Rer. \$8142. Case 15/71, Firma C. Mackprang, Jr. v. Commission, 17 Rec. 797 (1971); [1972] C.M.L.R. 52; CCH Comar. Mkt. Rep. 18155. Case 62/70, Werner A. Bock v Commission, 17 Rec. 897 (1972); [1972] C.M.L.R. 160; CCH Conar. MKr. REP. $\llbracket 8150$. Case 42/71, Nordgetreide GmbH \& Co. KG v. Commission, 18 Rec. 105 (1972); [1973] C.M.L.R. 368; CCH CoMm. MKT. REP. [8174. Cases $9 \& 11 / 71$, Compagnie d'approvisionnement, de transport et de credit SA et Grands Moulins de Paris SA v. Commission, 18 REc. 391 (1972); [1973] C.M.L.R. 529; CCH CoMns. MKT. Rep. ;8177. Case 96/71, R. \& V. Haegeman v. Commission, 18 Rec. 1005 (1972); [1973] C.M.L.R. 365; CCH CoMm. Mkx. Rep. \$8181. Case 134/73, Holtz \& Willemsen GmbH v. Council, [1974] ECR 1; [1975] C.M.L.R. 91; CCH Comr. Mkr. Rep. 18255 . Case 175/73, Union Syndicale et al. v. Council, [1974] ECR 917; [1975] C.M.L.R. 131. Case 18/74, Syndicat Général du Personnel des Organismes Européens v. Commission, [1974] ECR 933; [1975] C.M.L.R. 144. Cases 44, 46 \& 49/74, Marie-Lonise Acton et al. v. Commission, [1975] ECR 383. Case 72/74, Union Syndicale et al. v. Council, [1975] ECR 401.

19 Cases 106/63 and 107/63, Alfred Toepfer v. Commission, supra note 18. 
mission error. Seizing this opportunity, plaintiffs, large grain wholesale enterprises, applied for import licences on the zero-levy basis. When the error was discovered, German and Commission officials consulted and agreed on a course of action. The German Government invoked its safeguard power under a Council regulation which enabled the German agency to reject the requested licences. The Commission, pursuant to the same regulation, issued a decision directed to the German Government and "authorizing" its safeguard measure retroactively. It was this Commission decision that the plaintiffs sought to have annulled. The Court held that the plaintiffs had standing. They were concerned "directly" because the Commission decision was "directly applicable" to them; ${ }^{20}$ there was no need for any further action by the German Government. The plaintiffs were also concerned "individually" because the number and identity of the parties affected by the Commission's act ("no less than 27 companies") were determinable at the time the decision was adopted.

In the Bock case, ${ }^{21}$ as in the Toepfer case, the Commission responded to a request from the German Government and addressed a decision to that government authorizing it to reject already pending applications for import licences, including one by the plaintiff. In this case also the Court granted standing: The plaintiff was concerned directly (even though the formal rejection of the licences required an act of the German Government and in theory, it was argued, that government might have decided not to use the authorization to reject). The plaintiff was also concerned individually, because, as in Toepfer, his licence application was already pending at the time of the Commission decision and "the number and identity of importers thus affected was certain and determinable." 22

Finally, in the International Fruit case, ${ }^{23}$ the Commission, as part of a safeguard system designed to ensure stability of the apple market was given authority to consider the total quantity of apples for which import licences were requested and to decide what percentage, if any, of that quantity should be admitted. In that context, the Commission issued a "regulation" limiting the percentage and preventing acceptance of the applications for import licences filed during a specified past period with the Dutch Government. Plaintiffs whose applications were among those re-

20 The Court equated "direct concern" with the important Community concept of "direct applicability" and this raises some interesting problems which are beyond the scope of this article. The former is a procedural prerequisite for action before the Community Court; the latter goes to the merit of an individual's claim against a member state enforceable in a national court. For comments see Fromont in [1968] REc. Dalloz-Sirex, Jurusprudence 58; Peters in 3 C.M.L. Rev. 233 (1965).

${ }^{21}$ Case 62/70, Werner A. Bock v. Commission, supra note 18. For a comment, see Verougstraete, 8 CAHUER DE DROTT EUR. 666 (1972).

22 The Commission "was in a position to know that the decisions would affect only the interests and legal status of these importers. Under these circumstances the importers are set apart from all other persons in a manner similar to the addressee" (CCH CoMm. MKT. REP. at 7720).

${ }^{23}$ Cases 41/70-44/70, N.V. International Fruit Company et al. v. Commission, supra note 18. For a comment, see V.C. in 99 Journal DE DRort INTERNATIONAL. 687, $693(1972)$. 
jected were given standing to sue for annulment of the regulation which, the Court said, was in effect a bundle of individual decisions. ${ }^{24}$ Plaintiffs were concerned directly because after the Commission had acted the member governments had no intervening power, no discretion whether or not to accept or reject that action. The plaintiffs were also concerned individually because the Commission based its regulation upon applications already filed. Hence the number of the parties concerned was determined at the time of the adoption of the regulation even though the Commission, acting upon the aggregate quantity of apples for which import licences were requested as reported by the Dutch Government, had no knowledge of the identity or even of the number of the parties affected.

\section{The Court of Justice in Search of a Rationale}

The manner in which the Court and the Advocates General have employed the prerequisite of "direct concern" manifests an intense interest in maintaining the delicate balance between member state and community power, and we shall turn to this shortly. But the three cases where standing was allowed, seen against the background of all the cases where standing was denied, demonstrate the difficulties the Court and the Advocates General have encountered in drawing a line between what is and what is not of direct concern. Is the presence or absence of administrative discretion on the part of the member state under the challenged Community act the determining factor? And in which situations is such discretion present? In the Toepfer case where a Commission decision granted the requested authorization to the German Government the Court found a direct effect upon the plaintiff, although the Advocate General disagreed. In theory the German Government still had discretion whether or not to make use of the Commission's authorization but this did not seem to bother the Court. ${ }^{25}$ Yet in the Eridania case denying standing, one of the three dramas at the beginning of this article, the most remote possibility that the Italian Government might not make use of an authorization, which in fact it had recommended and to which it was financially committed, was enough for the Court to deny direct effect. ${ }^{26}$ In the Alcan case $^{27}$ where the Commission in a decision addressed to a government

24 Subsequently, the Court dismissed the case on the merits.

25 The Court said that the Commission decisions modifying or abolishing safeguard measures are "directly applicable" because Article 22 of the regulation under which the Commission acted provided that the Commission's decislon shall take effect immediately and therefore "[i]t would be illogical to say that a decision to retain protective measures had a different effect. . ." Alfred Toepfer v. Commission, supra note 18, [1965] ECR at 411.

20 Cases 10 and 18/68, Eridania, supra note 18. See also Adv. Gen. Roemer in Case 1/64, Glucoseries Réunies v. Commission, and in Case 26/62, Plaumann \& Co. v. Commission, and also in Cases 106/63 and 107/63, Alfred Toepfer v. Commission, supra note 18.

${ }_{27}$ Case 69/69, SA Alcan Aluminium Rearen et al. v. Commission, supra note 18. See also Case 25/62, Plaumann \& Co. v. Commission, supra note 18; cf. Adv. Gen. Gand in Case 38/64, Getreide Import v. Commission, supra note 18. 
refused an authorization, the Court found no direct effect on the plaintiff although the refusal eliminated any discretion on the part of the addressee government. ( The Advocate General found a scintilla of discretion in the possibility that the government might appeal the decision to the Courtl) ${ }^{28}$

The Court has struggled in a similar way with the second prerequisite, that of "individual concern." In the Eridania case, with which we began, the Court denied individual (as well as direct) effect, contrary to the advice from the Advocate General, to Italian sugar producers who were affected by a Commission decision granting subsidies to their competitors. But there were only twenty-five sugar producers affected. In another case, the Zuckerfabrik Watenstedt, not more than 30 raw sugar producers in the entire Community were in fact directly affected by a Council regulation and there was no real chance of new producers being added in view of the depressed conditions in the sugar market and the size of the necessary investment. ${ }^{29}$ Such "de facto individualization" satisfied the Advocate General but not the Court. Again, in Getreide-Import, despite the Toepfer ruling, a German importer-plaintiff was held not to be "individually" concerned by the Commission's decision fixing a price on imports for a specific date, although he was ultimately the only one to request an import licence on that date. ${ }^{30}$ It would seem that in the Court's view, the plaintiffs can be considered "individually" affected only if they are members of a group of persons whose identity and number are fixed and, in addition, if the challenged act has a retroactive effect on their legal position, that is, if the act affects their "vested rights." But it is not the unfairness or the actual harm in retroactive lawmaking that moves the Court to grant standing. In two more recent cases where a retroactive effect clearly existed, the Court found no standing. ${ }^{31}$

28 Advocate General Gand relied here on the views of his colleague Roemer in Plaumann. In the Alcan case Advocate General Gand pressed the argument that if the Commission's decision had granted the requested authorization to the government the decision would not have direct effect on the plaintiff; consequently, the actual decision in this case refusing the authorization must be equally without direct effect on him, apparently in the interest of symmetry. Case 69/69, Alcan, stupra note 18, CCH Conm. MKr. Rep. at 7256. Daig distinguishes the decisions in which the Commission addresses an order, prohibition, or authorization to a member state. Daig in KOMIMENTAR, supra note 9, at 232-33.

${ }^{29}$ Case 6/68, Zuckerfabrik Watenstedt v. Council, supra note 18 . See also Case 1/64, Glucoseries Réunies v. Commission, supra note 18, where both the Advocate General and the Court found no individual effect.

30 Case 38/64, Getreide-Import Gesellschaft v. Commission, supra note 18. For comments on this case, see Mailänder, Privater Rechtsschutz im Recht der Europäischen Wirtschaftsgemeinschaft, [1965] BETrIEB 1312; ULE, supra note 13 at 17-19. The Court attempted to distinguish the case from Toepfer on the ground that, unlike the Toepfer situation, the Commission did not know of the plaintiff's application at the time of its decision. Bebr feels this factual difference might explain the two different holdings "at least partially." Bebr, Recours en annulation et en carrence, supra note 13, at 315. See also Case 30/67, Industria Molitoria Imolése v. Council, supra note 18.

31 In Case 69/69, Alcan v. Commission, supra note 18, the Court found no direct concern and remained silent on the issue of individual concern although Advocate Gen- 
We might note that in the Glucoseries case, the Court, after reciting the Plaumann formula, proceeded to inquire into the "general economic scope" and "purpose" of the Commission's act." The preoccupation with the "purpose" of the challenged act may suggest one reason why the Court may have granted standing in Toepfer and Bock, two of the three Community cases where standing was allowed. In Toepfer some evidence suggested a collusion between national and Commission officials to erase an administrative error through means not entirely compatible with good administration, ${ }^{33}$ and in Bock an improper delay and perhaps arbitrary recourse to a protective measure. It is significant that in both cases the Court ultimately annulled the contested act in proceedings on the merits. In the International Fruit case, the third case of the triad, the Court may have been concerned, in granting standing, that the Commission should not be in the position of precluding judicial review of its act by labelling it "regulation" rather than "decision." ${ }^{4}$ This somewhat speculative line of analysis would suggest that in reality the Court may be inclined to look beyond jurisdictional arguments and grant standing where it senses an element of irregular administration.

This possibility aside, it is fair to say in summary that with respect to "direct concern," the Court of Justice has sought to give content to the requirement by invoking a Community interest in preserving the discretion of member governments; but the distinctions the Court has made on this basis are so illogical that one may question whether there is yet a workable or meaningful doctrine of "directness." As for the "individual concern" prerequisite, the Court seems to require that a plaintiff show something in the nature of an exclusive legal right analogous to a "vested right," something similar in its impact, as we shall see, to the original common law standing test in American federal law.

eral Gand held individual concern to be present. In Case 61/69, La Compagnie fransaise v. Commission, supra note 18, the Court found no individual concern even though, according to the plaintiff, the contested provision of the Commission regulation applied to a group of specified enterprises (including the plaintiff) since these enterprises were positively known and identifiable even before the contested provision was issued. The Court stated: "The fact that a transitional rule concerns only certain situations created prior to a date which it sets and which are therefore often determined even before the rule goes into effect does not prevent such a rule from being an integral part" of and sharing the general character of a regulation. Thus retroactivity alone is not enough "unless there is a misuse of discretionary power."

CCH CoMMr. MKT. REP. at 8323.

3: Case 1/64, Glucoseries Réunies v. Commission, supra note 18.

${ }^{33}$ Kovar in 93 Journal DE DRort inTERnational 707, at 711-12 (1966).

34 In his opinions in the International Fruit case, Advocate General Roemer stated: "[I]t is extremely doubtful that we are actually dealing with a regulation in the sense of the definitions that were so often given in previous decisions of the Court" (CCH Comm. MkT. Rer. at 7635). But see Case 64/69 La Compagnie française, supra note 18. In that case, denying that a provision in a regulation was of individual concern to the plaintiff, the Court said: "Unless there is a misuse of discretionary power, such a provision shares in the general legal nature" of the regulation (CCH Comar. MkT. REP. at 8323). 


\section{Erements of Legal Policy}

One may well wonder what considerations have induced the Court to reject even the modicum of Hlexibility suggested by its own Advocate General, ${ }^{35}$ particularly if we recall, by way of a contrast, the Court's imaginative and teleological approaches to other institutional questions. ${ }^{36}$

(1) We have already mentioned the political concern with respect to member governments. A real likelihood of the exercise of member state discretion in implementation does appear to be relevant to the technical definition of a "direct" concern in the Community act being challenged. But Advocate General Gand went so far as to invoke "diplomatic courtesy" dictating that state discretion and state "sovereignty" not be impaired, ${ }^{37}$ language reminiscent of the International Court of Justice which umpires international disputes among states.

While prudence is obviously in order for a freshly established judicial tribunal in a body politic where states play a crucial part, the method by which the Court has sought to limit its jurisdiction is, as we have suggested, open to question. Moreover, can the Court seriously assert respect for states rights and sovereignty when a plaintiff, claiming present harm, is offering to show that the contested Community act is illegal and thus can not serve as a legal basis for further state action?

(2) Another and perhaps more compelling consideration was articulated by Advocate General Lagrange: Since the Treaty is largely a "traité cadre" or framework law which normally must be implemented by general regulations, the possibility of even a partial annulment of such a regulation poses "an extreme danger" to the system, if, as is frequently the case, the regulation represents a laborious compromise reached in the Council pursuant to the unanimity rule or practice. ${ }^{38}$ The solution, he suggests, lies in increasing the role of the European Parliamentary Assembly in the legislative process so that there is less danger of paralysis if the compromise is annulled. In the present circumstances, it may also be recognized that it is difficult to brand a Council regulation unanimously adopted by representatives of the member states as "illegal" even where it appears to be inconsistent with the Treaty: it would be to a degree a modification of the basic law albeit in disregard of the amending procedure. These considerations, however, would hardly apply to standing with respect to Council regulations of lesser stature, routine regulations of the Commission, or to Commission decisions addressed to other persons (particularly to private parties).

${ }^{35}$ E.g. Advocate General Roemer in Case 6/68, Zuckerfabrik Watenstedt v. Commission, supra note 18. It is, however, difficult to reconcile Mr. Roemer's own position in this and in the Glucoseries case 1/64, supra note 18 , unless one concludes that the lapse of four years and the intervening experience with the system led him to change his mind.

36 See Stein, Review of Europäisches Gemeinschaftsrecht by Hans Peter Ipsen in 22 AM. J. CoMp. L. 156 (1974).

37 Case 69/69, Alcan, supra note 18, CCH CoMM. MKr. REP. at 7256.

$38 \mathrm{M}$. Lagrange very likely had in mind the type of Council regulation comparable in substance if not in form to an act of Parliament which, according to the French conception of separation of powers, could not be made subject to judicial review. 
The Court may also have had in mind another argument advanced by Commission jurists with respect to Council regulations which the Commission is required to implement. Even where a plaintiff feels directly injured by a general regulation which he considers illegal, he should be denied standing, it is said, until the regulation is actually applied to him by a Commission decision addressed to him, at which time he would have standing to contest the decision. ${ }^{39}$ Apart from making rational business planning impossible, the argument does not take into account a potentially serious or even irreparable harm that might result from the delay.

It has been suggested that the Court ought to develop more nuanced criteria of standing depending upon whether the act is predominantly "legislative" or purely "administrative," such as a Commission decision addressed to a government ${ }^{40}$ and responding to its request for a special exemption from a general rule. ${ }^{41}$

(3) The political considerations are no doubt buttressed by the inherent aversion of administrators everywhere (including the United States) to judicial control. Attorneys appearing in defense of the Council and the Commission have been uncompromising and consistent in their opposition to plaintiff standing. The Court of Justice is not a federal court, and even the Supreme Court of the United States would hesitate to rule in a controversial matter against both the Congress and the Executive. In very few instances has the Court of Justice ventured substantially beyond the Commission's position in important systemic questions. The opposition of the Commission and Council makes it difficult to do so on the standing issue. While the Commission has invariably urged liberal, purpose-oriented interpretations in defining the scope of its own power or the power of the Communities generally, it has taken the narrowest and the most mechanistic position in the standing-to-sue cases where the question was one of potentially curbing its own power. ${ }^{42}$ However, at this stage of development, the opposition of Community attorneys to a more liberal interpretation may be due as much to the customary bureaucratic aversion

20 In that case, the Court could also consider the legality of the Council regulation; if it found that the regulation infringed the Treaty, it would annul the decision, holding the underlying regulation inapplicable pursuant to Article 184.

s. It is, in any case, doubtful that the Court would want to adhere to its present narrow interpretation of "individual concem" should a private party contest a decision addressed not to a member state but to another private party, as is likely to occur particularly in the field of competition. E.g., a Commission decision addressed to parties to a restrictive agreement which exempts the agreement from the Treaty prohibition and third parties (competitors) feel aggrieved by the decision. P. J. G. Kapteyn and P. VerLoren van TheMaAt, Introduction to the Law of the European Cominunties After the Accession of New Mextber States at 169 (1973).

"1 A. W. Green, Political INtegration by Jurisprudence-The Work of the Court of Justice of the European Condmontties in European Polttical IntegraTION 111 (1969).

42 Some of the Commission's extreme positions were criticized by the Advocates General. We were able to find only one case in which the Commission's counsel, having first taken a rather untenable position against standing on one of the two requirements, reversed himself in the course of the proceeding. Case 38/64, Getreide Import Ges. v. Commission, supra note 18, Opinion, [1965] ECR at 211. 
to any deviation from an established policy line as to a strong attachment to principle.

(4) The Court has said that it cannot modify the Treaty. In one case the plaintiff contended that, if recourse to Article 173 were denied to him because of a narrow interpretation of the text, he would be deprived of all judicial safeguards both under Community law and under national law, which would be contrary to the basic principles governing all member countries. $^{43}$ The Court responded that these considerations could not "be allowed to override the clearly restrictive wording of Article 173, which, it is the Court's task to apply." $\$ 4$ Yet at least in the case of an individual contesting a decision addressed to a third party, the question involvedthe interpretation of the words "direct and individual concern"-is hardly a matter of Treaty modification. 45

Of course in many, though not in all cases, the plaintiff would in fact have recourse to national courts, and, via the procedure of Article 177, to the Court of Justice, which then would have an opportunity to pass upon the validity of a decision or regulation in a "preliminary ruling," with a binding effect upon national courts. This procedure involves substantial cost and delay. ${ }^{46}$ Nevertheless, from the very outset the Court has interpreted access to national courts for the purpose of enforcing individual

43 Kovar criticizes such potential "denial of justice," supra note 33, at 710.

44 The Advocate General buttressed this view by adding that:

[t]his argument can only avail if the applicants first prove that the Treaty gives private individuals concerned a guarantee of direct and complete legal protection, for it clearly cannot fall within the powers of the Court of Justice to amend the Treaty on this point.

Case 40/64, Sgarlata et al. v. Commission, supra note 18, Opinion, [1965] ECR at 235. 45 In defining the reach of Article 173(2) the Court must have had in mind the long-range consequences in national legal systems if it ignored the principle underlying national constitutions that, in a system of power relationships based on law, an affected citizen must presumptively have some remedy against illegal official action. The German Federal Constitutional Court has ruled that at this stage of integration it retains power to review a Community act for compatibility with the Federal Constitution if it is claimed that the act violates a basic right protected by the Constitution. Decision of May 29, 1974, 37 BVerfGE 271 (1974).

${ }^{46}$ Since, according to Article 177 , only the court of last instance is required to refer the Community law questions to the Court of Justice, it may take years before the case reaches the highest national court. ULE (supra note 13, at 19-20, 22) considers this route "a difficult and prolonged detour." He suggests (de lege ferenda) a modification of Article 173(2) that would omit the requirement of direct and individual concern and allow standing to contest a decision addressed to another if the plaintiff's "legally protected interests" are affected. Thus the Treaty would conform to German administrative law which allows standing in case of impairment of a right as well as a legally protected interest. Ule cites $\mathrm{J}$. H. Kaiser, Mailänder, and possibly Badura as supporting this suggestion. He cites Zweigert, Lagrange, Mathijsen, Catalano, and Ehle as urging replacement of the requirement of "direct and individual" or (Daig) of "individual" so as to broaden access to the Court. Zweigert, Empfiehlt es sich, Bestimmungen ïber den Rechtsschutz zu ändern? HAUPTREFERAT, ZEIIN Jahre Rechtssprechung des Geruchtshofs der EuropäIschen GeMeinschaften 58097 (1965). Rapport fait au nom de la Commission juridique sur la protection juridique des personnes privées dans les Communautés européennes, Rap. M. A. Deringer, Parc. Eur. Doc. 39, 3 May 1967. 
rights derived from Community law in a most liberal way, far beyond what may have been the intent of the authors of the Treaty. The Court has clearly preferred to enhance its jurisdiction, and the protection of individuals, through this avenue which is particularly appropriate to the symbiotic Community system, rather than by opening up the individual's direct access pursuant to Article 173. In this, the Court has succeeded beyond any expectation, considering the many cases referred to it by national courts from the member states. Because of the political problems which a member state or a Community institution faces in initiating an action against an institution or a state before the Court, the Article 177 procedure has become the most frequently employed course for enforcing Community law. More recently, the Court has also given a more liberal interpretation to the Treaty provisions allowing private persons to sue the Community for damages caused by an act of a Community institution. ${ }^{17}$ The question for the future will be whether these procedures are sufficient.

(5) It is interesting to speculate whether the Court has been influenced in this field by the laws of the member states.

The Court's records show that the Advocates General, if not the Court itself, have at least had in mind the relevant national laws and practices. But there has been no unanimity of opinion. M. Lagrange, the distinguished first Advocate General from the French Conseil d'Etat, was prepared to discount the fact that "the legal situation within the Community is undoubtedly less favorable [to the plaintiff] than that which has been reached for a greater or lesser length of time by some of the Member States, but it is similar to that known in other States." 48 His counterpart, the able Mr. Roemer, coming from private corporate law practice in Germany, appeared troubled, in 1968 at any rate, by the Court's formalistic approach as compared with rules applied by the German Federal Administrative Court, and particularly by the possible constitutional implications of leaving a citizen without any remedy. ${ }^{49}$ The current German and Italian Advocates General appear to take somewhat different views on the relevance of national administrative law solutions to analogous Community cases. ${ }^{50}$

${ }^{47}$ Cf. Case 25/62, Plaumann \& Co. v. Commission, supra note 18, with Case 4/69, Alfons Lütticke GmbH v. Commission, 17 Rec. 325 (1971), CCH Conrar. Mkт. Rep. \8136. See also Case 5/71, Aktien-Zuckerfabrik Schöppenstedt v. Council, 17 REc. 975 (1971), CCH Cosrar. Mrr. Rep. ¡8153; Gilsdorf, Die Haftung der Gemeinschaft aus normativem Handeln auf dem Hintergrund der Rechtssprechung des Europäischen Gerichtshofs, 10 EUROPARECHT 73 (1975).

4 Cases 19/62-22/62, Fédération Nationale v. Council, supra note 18, [1962] ECR at 486.

49 Case 6/68, Zuckerfabrik Watenstedt v. Council, supra note 18, [1968] ECR at 418; Cases 10 \& 18/68, Società "Eridania" v. Commission, supra note 18, CCH CoMng. MKT. ReP. at 843I-34.

so Case 175/73, Union Syndicale et al. v. Council, supra note 18, [1974] ECR at $9: 30$ (Opinion by Mr. Reischl); Case 18/74, Syndicat Général du Personnel des Organismes Européens v. Commission, supra note 18, [1974] ECR at 948 (Opinion by Mr. Trabucchi). 
In any event, although the Court has not hesitated in other contexts to canvass national laws for "general principles" that may be common to them, we cannot find any evidence that the Court may be getting ready to soften its strict posture in this area to reflect some of the more liberal trends in national laws. The Court's present position is reminiscent of the earlier German standing requirement that plaintiff show infringement of "subjective public right" rather than the more flexible formula evolved by German doctrine holding "legally protected interest" sufficient. Obviously the liberal French jurisprudence has also had little impact.51

(6) One factor which may explain the apparent absence of effective pragmatic pressures on the Court to grant broader access is the still relatively limited scope of the Community regulatory power, confined essentially to customs union, movement of factors of production, and competition. Some of the economic and noneconomic forces and interests such as environmental and consumer protection, which have had such impact on the liberalization of the American rule, operate thus far, if at all, at the national level and are only beginning to be reached by Community power.

(7) Finally, although the Court has been reticent on the subject, an important concern may be the possibility of multiplicity of suits should citizen access to the Court be defined in broad terms. We shall return to this problem after a discussion of the American experience.

\section{Standing in U.S. Federal Courts: The Common Law Test and Its Demise}

The Community Court's difficulties in applying its current interpretation of Article 173 are similar to those experienced by American federal courts in the decades before 1970. American doctrine has not been troubled by a basic distinction between "decisions" and "regulations." Both have long been judicially reviewable "administrative action." 52 But, as we have seen, in specific circumstances "regulations" can be viewed in Community law as a "bundle of individual decisions," 53 and it is likely that the classification of Community action as a "regulation" or not for purposes of the first part of the second paragraph of Article 173 will follow and simply express the resolution of the real problems of standing, which have to do with the "individuality" and "directness" of the plaintiff's stake in the case. Here the parallels between American and Community developments are striking.

A concern that the judiciary not undermine the sense of responsibility within administrative agencies for the legality of their programs, or interfere with the process of interest group accommodation carried on by agencies in the development of a program, has led to doctrines in American

51 The German courts and the doctrine have mitigated the rigor of the language of the statute requiring that plaintiff be injured "in his rights." $\$ 42(2)$ Verwaltungsgerichtsordnung of Jan. 21, 1960. See also infra, text at note 60.

${ }^{52}$ See, e.g., CBS v. United States, 316 U.S. 407 (1942); Administrative Procedure Act, 5 U.S.C. $\$ 551$ (13), 7 U.S.C. $\$ \$ 702,704,706$ (Supp. V, 1965-1969).

53 Supra text at note 24 . 
federal administrative law designed to allow postponement of judicial review where discretionary agency steps are still to be taken before enforcement of an agency decision or regulation. These, the doctrines of "finality" and "ripeness," are now treated separately from the law of standing. Whether that part of the Community standing test that focuses on member state discretion is meant to take into account similar concerns is difficult to know, in view of the way the "directness" prerequisite has been administered. It is quite clear, however, that access to judicial-review under the American doctrines of "finality" and "ripeness" does not turn simply on whether or not there is discretion. A showing of discretionary implementation is only the beginning of an analysis of the relative costs and benefits of delaying judicial review. The argument that a plaintiff has too indirect and attenuated a concern with administrative action if it does not fix rights or obligations, an argument still made by government attorneys, has been labeled by the Supreme Court as having "the hollow ring of another era." 54

With regard to "individuality," the basic rule of standing in the United States until the late nineteen sixties was the common law test, under which the plaintiff could invoke the jurisdiction of a court only if he could point to a private legal right that would be violated by a named government official if that official failed to show that his action was authorized-a test which still obtains in many of the states today and which resembles the formula now employed in the Court of Justice. It was only in 1970 that the U.S. Supreme Court expressly "discredited" this test and turned to the Administrative Procedure Act for a definition of standing. ${ }^{55}$ However, the formula drawn from the Act to replace the so-called "private legal right" test did not burst upon us full blown. There is a history which merits a brief account, for it indicates that we may be dealing with underlying currents of thought and concept that are likely to have an impact on societies functioning in a comparable frame of reference.

The attack upon and demise of the "legal right" test had two main historical roots. One involved "economic" interests and the other "noneconomic." On the economic side, it has been a rule of the common law that no person has a "right" to be free of competition. When a person came into court and complained that he had suffered injury through the increased competition of someone else made possible by an allegedly illegal government act or subsidy, the classic response was that he had no standing to seek an injunction against the illegal act hurting him because he had not shown the invasion of a legal right of his "own." For instance, in 1938 competing private utilities were held to have no standing to challenge the legality under the National Industrial Recovery Act of a program of public work grants to municipalities for construction of electric distribution systems. In reading this case one immediately thinks of Eridania.

54 Marine Terminal v. Rederiaktiebolaget Transatlantic, 400 U.S. 62, 71 (1970); sce Vining, Direct Judicial Review and the Doctrine of Ripeness in Administrative Law, 69 Mirch. L. Rev. 1443 (1971).

wi Supra note 8. 
The U.S. Supreme Court held that a person injured by government action can not challenge that action in court unless the injury resulted in the violation of a legal right, ${ }^{56}$ which the Court later defined as "one of property, one arising out of contract, one protected against tortious invasion, or one founded on a statute which confers a privilege." 57

There was never a self-evident logic to a position that because a business had no right to be free of competition it had no right to be free of illegally created competition, and as government was seen to intervene more and more into the market and affect and determine the relative aclvantages of the players in the market, business interests became more and more determined to gain access to the courts to review the legality of administrative actions affecting them in this most important way. One response by the courts was to view the specific standing provisions often written into statutes creating the regulating agencies and often couched in vague terms-conferring standing for instance on "aggrieved" personsas congressionally mandated exceptions to the courts' own self-imposed and restrictive requirement of a legal right. ${ }^{58}$ Much more threatening to the conceptual integrity of the legal right test, however, was the conclusion that if a person or group of persons could show that they were in some sense the intended beneficiary of the establishment of an administrative regulatory scheme or any part of it, they could be viewed as having "quasi-property" rights in the common law sense, and standing followed when government officials administered the scheme in such a way as to deny the benefit. This was a transparent circumvention of the legal right test, for such persons as the private utilities operating around the territory of the Tennessee Valley Authority, and claiming to be the beneficiaries of that authority's limited geographical jurisdiction, had no private legal rights under the common law of property and none granted them by the statute. Nor was their standing arguably mandated specifically by Congress. Their quasi-property rights were recognized solely for the purpose of standing to challenge the administrative action. ${ }^{59}$ This search for and discovery of "beneficiaries" of the regulatory scheme was extended into a number of fields beyond those of economic competition. The concept recalls the "legally protected interest" test in German administrative law which, as we have mentioned earlier, German doctrine constructed as a more flexible alternative to the rigid standing requirement that the plaintiff must show a "subjective public right." 60

56 Alabama Power Co. v. Ickes, 302 U.S. 464, 479 (1938).

57 Tennessee Electric Power Co. v. TVA, 306 U.S. 118, 137-38 (1939).

${ }^{58}$ See, e.g., Associated Industries v. Ickes, 134 F.2d 694 (2d Cir. 1943), vacated as moot, 320 U.S. 707 (1943).

${ }^{59}$ See, e.g., Hardin v. Kentucky Utilities, 390 U.S. 1 (1968).

oo See supra text at note 51. See also ULE supra note 13, at 21-22. Fromont believes, referring to the Toepfer case, that the Court of Justice in fact adopted the "subjective public right" test without saying so in so many words. Fromont, L'influence du droit français et du droit allemand sur les conditions de recevabilite du recours en annulation devant la Cour de Justice des Communautés européennes, 2 REv. TRMM. DR. EUR. 47, at 63 (1966). See also Fromont, Der Rechtsschutz gegen Massnahmen der Verwaltung im Europa der Sechs, 4 Eunoparecht 202 (1969). 
The second major thrust against the common law test concerned noneconomic values. It is usually impossible to claim any private or exclusive right to the beauty, health, safety, or recreational opportunities so widely regulated by modern administrative bodies. The money loss resulting from a bureaucratically dictated change in relative economic advantage was at least discrete and theoretically measurable, like other private harms which the common law traditionally considered and sometimes prevented. A noneconomic loss often did not resemble a loss of "property" in any way. Yet it might be of even greater importance to an individual; and as the growth of legislation and regulation established causal connections between noneconomic losses and official action, lower federal courts began to give remedies to individuals against such action when it was illegal. Consumers of television were granted standing to challenge the licensing of particular television stations ${ }^{61}$ and consumers of food were granted standing to challenge the legality of adding color to oleomargarine. ${ }^{62}$ Frequently the courts claimed to be interpreting the general language contained in specific statutory standing provisions in various licensing acts, provisions which most observers would have originally thought were included for the benefit of persons and groups, such as manufacturers of food or chemicals or television licensees, economically associated with the regulatory scheme in question and subject to administrative sanctions. These cases in the lower courts go back to the 1940's and 50's, but appeared in great numbers during the 1960's and were ultimately cited with approval in the 1970 decisions of the Supreme Court which brought about the major change.

\section{The New Test}

Technically, the change was effected by holding that the Administrative Procedure Act, which had been enacted more than a quarter of a century earlier, was a source of standing independent of both the common law and the special standing provisions incorporated into the various acts setting up administrative agencies. The Act applies to all agencies unless they are specifically excepted, and provides that any person is entitled to judicial review of agency action if he "suffers legal wrong or is adversely affected or aggrieved within the meaning of a relevant statute." Even though the term "legal wrong" was used in the statutory language, the Court declared that the legal right test of the common law, under which, it will be remembered, the plaintiff stated a cause of action only if he showed a private legal right invaded by a government official acting under the color of law, was discredited. The Court used the word "discredited" and was unanimous in this regard. The Court then went on to construct a new formula for the standing of private parties in challenges to administrative action, namely that the party must be "injured in fact" and must show that "the interest he is seeking to protect"-to quote the language which the Court has since repeated in subsequent cases-is "argu-

is Office of Communication of United Church of Christ v. F.C.C., 359 F.2d 994 (D.C. Cir. 1966).

62 Reade v. Ewing, 205 F.2d 630 (2d Cir. 1953). 
ably within the zone of interests protected or regulated by the statute in question," the "statute in question" being the statute setting up the administrative agency and providing substantive standards for judging the legality of its actions. A French lawyer reading the language of this formula might immediately think of his own "interêt a agir," the rather liberal standing test developed by the Conseil d'Etat. ${ }^{83}$

Applying the new test, the U.S. Supreme Court granted standing to a trade association of independent data processing companies, and later to a travel agency, to challenge the legality of regulations issued by the Comptroller of the Currency which permitted federal banks to compete with them by expanding into the fields of data processing and travel services. ${ }^{04}$ The Court made clear that it was not relying on any evidence that Congress had intended to make data processors or travel agents specific beneficiaries of bank regulation. ${ }^{65}$ Two years later, the Court seemed to imply that it would hear the challenge of the Sierra Club, a conservationist group, to actions by federal officials of dubious legality which had permitted Disney Enterprises to begin the development of a wilderness area in a national forest in California, providing that the club showed that it spoke on behalf of members who were injured, whether in economic or noneconomic fashion, in their use of the wilderness area. ${ }^{68}$ Then, in 1973, the Court did grant standing to a group of law students who used a national park and who challenged a railroad rate regulation that might have the effect of polluting the park. ${ }^{67}$ In none of these cases could a claim to a personal legal right be made out, nor were there specific provisions in the statutes governing the agencies in question for judicial review of the agency decision at the request of the plaintiffs.

One cannot doubt that the conceptual and pragmatic pressures that led to these results would have succeeded in finding some other mode of expression if the language of the Administrative Procedure Act had not been at hand ready for use. ${ }^{68}$ Had the judiciary truly conceived itself as lim-

68 Commissaire du gouvernement Mosset stated in his well-known conclusions that standing to institute judicial review of administrative action will be given if the contested decision "injures the plaintiff materially or morally" and if the consequences of the decision affect plaintiff in his capacity as a member of a "defined or limited category." C.E. 26 Oct. 1956, Association Générale des administrateurs civils, R.D.P., 1956, 1309, cited in Fromont, L'influence du droit . . . , supra note 60, at 56.

64 The principal case was Association of Data Processing Service Organizations, Inc. v. Camp, 397 U.S. 150 (1970), described supra at note 2. See also Barlow v. Collins, 397 U.S. 159 (1970); Amold Tours, Inc. v. Camp, 408 F.2d 1147, 1151 (1st Cir. 1969), vacated 397 U.S. 315 (1970), reaffirmed 428 F.2d 359 (1st Cir. 1970), reversed 400 U.S. 45 (1970).

${ }^{65}$ Arnold Tours, Inc. v. Camp, supra note 64.

Be Sierra Club v. Morton, 405 U.S. 727 (1972).

67 United States v. S.C.R.A.P., 412 U.S. 669 (1973).

68 The Court commented at the time and has emphasized since that rules of standing are developed by the Court "for its own governance." Data Processing Service Organizations, Inc. v. Camp, supra note 2, 397 U.S. at 154; Warth v. Seldin, 95 S. Ct. $2197,2205,2215$ (1975). The Court had never required a statutory basis for its legal right test. In essence the Court shifted the judicial presumptions within which legislatures must work. Legislative materials are now searched for a specific intent to deny standing rather than a specific intent to grant it. 
ited to the protection of private rights except in those instances where the legislature expressly instructed it to go beyond that role, a quite reasonable interpretation of the standing language of the Act was available. As we have noted, many of the special standing statutes providing for judicial review of certain agency actions in specified circumstances use the term of art "aggrieved" to designate those persons who may seek redress, and it was open to the Court to conclude that the language of the Administrative Procedure Act which suggested a ground of standing other than "legal wrong," or invasion of private and personal legal right, was meant to do no more than refer to those situations where specific statutory standing was given to individuals by such statutes. But the Court did not do so, and held instead that standing emanated from the Administrative Procedure Act itself. Although grounded in legislative languageas the formula for standing in the Court of Justice is grounded in Article 173-the decision to hear challenges to the legality of administrative action in a larger number of situations was clearly a matter of $j u d i c i a l$ choice.

It is, however, far easier to see what American courts have put behind them than to see what lies ahead. Lower federal courts have found the new standing formula difficult to administer without opening their doors to all litigants who have demonstrated a personal concern for the values affected by the challenged action sufficiently strong to support the costs of litigation. ${ }^{\circ 9}$ Explicit approval of such a result would not be incompatible with existing jurisprudence, ${ }^{70}$ and, as we shall note below, might cause relatively few practical difficulties. But there are indications that the Supreme Court is not prepared to go so far. In constitutional judicial review of congressional action, litigants have sought to use developments in the review of administrative decisions to establish the standing of persons in their capacity as "citizens" to enforce the Constitution. In its most recent decisions, the Court has explicitly rejected the concept of the "public action" ${ }^{71}$ and while, as we have noted, review of acts of Congress involves considerations different from those governing the review of administrative action and has proceeded on doctrinely separate routes, the Court used language in justifying its limitation on constitutional standing that may apply to both the administrative and the constitutional areas. ${ }^{72}$ Ironically, the difficulties in charting the reach of the new Ameri-

is See, e.g., Coalition for the Environment v. Volpe, 504 F.2d 156 (8th Cir. 1974); Diggs v. Schultz, 470 F.2d 461 (D.C. Cir. 1972), cert. den. 411 U.S. 931 (1973); Ballerina Pen Co. v. Kunzig, 433 F.2d 1204 (D.C. Cir. 1970).

70 See, e.g., Jaffe, The Citizen as Litigant in Public Actions: The Non-Hohfeldian or Ideological Plaintiff, 116 U. PA. L. Rev. 1033 (1968); SAX, Defendne tHe ENVIRONAIENT (1970).

il See, e.g., Warth v. Seldin, supra note 68; United States v. Richardson, 418 U.S. 166 (1974).

72 In addition, in one case following the announcement of the new formula three members of the Court turned again to a special standing statute using the term "aggrieved" to justify hearing the challenge of a white resident of a housing project to the legality of the housing agency's alleged exclusion of black applicants. The Justices did, however, concur in the majority decision to grant standing, which was based on general principles rather than any specific permission by the legislature. Trafficante v. Metropolitan Life Ins. Co., 409 U.S. 205 (1972). 
can administrative law standing formula and in determining whether a constitutional challenge is more than a "public action" are now discussed in terms of whether the plaintiff's injury or interest is sufficiently "individual" and "direct," ${ }^{3}$ the very terms mandated by Article 173 for equivalent discussions in the Community. But all we can say with assurance is that the questions of "directness" and "individuality" are not to be answered in the United States according to whether or not a private and established right is at stake in the case.

\section{Concluding Observations: How Relevant is FEDERAL EXPERIENCE?}

What has happened in the United States is a reflection of and indeed now a principal symbol of a significant change in the conception of the role of a judiciary in a modern administrative state. Courts are no longer to be viewed as restricted to the settlement of private disputes and protecting vested private rights against government intrusion. The very notion of a self-sustaining sphere of private rights into which government action "intrudes" is now difficult to grasp. And with the growth of government it has been increasingly widely perceived that leaving government activities outside that sphere to take care of themselves may well mean leaving individual government officials essentially unchecked. Neither bureaucratic processes nor the legislature itself is in fact capable of policing the activities of government agencies on a day to day basis. Not even the U.S. Congress with its massive staff of experts can attend to details or tend to them in time. The burden of inertia is such that relegating a challenger to a legislative remedy is itself a decision on the merits.

In sum, we think the American courts and Bar have at last acknowledged that they and their processes play an integral part in the business of government. Of course, in a pluralistic democratic society it is the elected legislature that in principle has power and responsibility to determine the hierarchy of common values and resolve conflicts among them. But no society pursuing a multitude of public values of different weight and importance through a multitude of largely independent implementing agencies can do without courts and still hope to achieve a satisfactory realization of its goals. The Supreme Court now speaks of "private attorneys general," a phrase which appeared as early as 1943 in the American judicial vocabulary. ${ }^{74}$ Responding to their initiative, American courts are holding in check and inquiring into the legality of challenged agency action on behalf of interests of a broader and more general concern than the private interests in contract and property traditionally protected.

The Rome Treaty has made the Court of Justice an important part of its mechanism for achieving its goals. In a body without an elected legis-

\footnotetext{
${ }^{73}$ See, e.g., Linda R. S. v. Richard D., 410 U.S. 614 (1973); Sierra Club v. Morton, supra note 66.

${ }^{74}$ Associated Industries v. Ickes, supra note 58. See also F.C.C. v. Sanders Bros. Radio Station, 309 U.S. 470 (1940); Association of Data Processing Service Organizations, Inc. v. Camp, supra note 2.
} 
lature, where law is made by national and transnational executives through processes shielded from the glare of publicity, the judicial role is if anything even more essential than in a mature federation. As a single tribunal serving the entire expanse of the Community, the Court may understandably be concerned with judicial economy and avoidance of cranky proceedings and multiplicity of suits. Both these dangers have troubled American courts. The burden of merely being required to respond to an argument on the merits and the potential for harassment resulting from a broadened test of standing are no doubt among the factors making the exploration of the boundaries of the new American formula a rather cautious one, particularly in the noneconomic area. But the State of Michigan and several other American states are experimenting with environmental protection legislation that permits extremely broad access to courts, and the experience to date is that no large scale multiplicity of suits is developing. Rather the impact has been on the attitudes of the administrators and on proceedings before them. ${ }^{7 \overline{ }}$ If in fact a great number of suits, perhaps of an identical nature, are brought with a shift from a "private right" basis for standing to the new formula, and given the cost of litigation that is dubious, then the problem can be handled through consolidation and class action procedures. ${ }^{76}$ Whether a suit is cranky or not seems to us a matter for the merits. If it is frivolous, it can be disposed of far more rapidly by getting to the merits than by litigating the question of standing.

It has clearly been a wise judicial policy for the Court of Justice to encourage private plaintiffs to bring their complaints before their own national tribunal, despite the additional risks, cost, and delay which this may entail. But as the scope of the Community regulatory powers broadens to include other fields and affect other values, economic and noneconomichealth and safety, environment, consumer protection, energy conservationthe Court may well feel called upon to broaden direct access by private complainants. If it does, we suggest that it will act not only to protect private interests but also to advance the common interest in effective enforcement of Community legality and broader participation of citizens in Community administration.

$7 \pi$ Sax and Dimento, Environmental Citizen Suits: Three Years' Experience Under the Michigan Environmental Protection Act, 4 EcoLocY L. Q. 1 (1974).

7" See Abbott Laboratories v. Gardner, 387 U.S. 136, 155 (1967). Although the Court of Justice has made full use of the consolidation procedures, most recently it has defined the standing to sue of associations so as to cause numerous separate actions to be filed by individual association members instead of a single action by the association itself. Case 18/74, Syndicat Général du Personnel des Organismes Européennes v. Commission, supra note 18. See Cases 44, 46 \& 49/74, Marie-Louise Acton ct al. v. Commission, and Case 72/74, Union Syndicale et al. v. Council, supra note 18. The Court held, with the support of the Advocate General, that although an association has a general capacity to appear in court as a "legal person," and may also participate as an intervenor, it cannot sue for annulment in its own name unless it can show that it was aggrieved in its own functional rights (e.g., violation of its contract with the public agency) or upon an express "mandate" from the aggrieved members. 